IP Periodica Polytechnica Chemical Engineering

61(4), pp. 288-294, 2017

https://doi.org/10.3311/PPch.10689

Creative Commons Attribution (i)

RESEARCH ARTICLE

\section{Novel Solid Base Catalyst Derived from Drinking Water Defluoridation for Biodiesel Synthesis}

\author{
Jharna Gupta $^{1}$, Madhu Agarwal ${ }^{1 *}$, Ajay Kumar Dalai ${ }^{2}$
}

Received 03 March 2017; accepted after revision 25 June 2017

\begin{abstract}
In this study, a novel heterogeneous catalyst was synthesized from drinking water treatment sludge obtained during defluoridation in biodiesel production by transesterification. More specifically, the sludge was converted into an effective catalyst by calcination at $950{ }^{\circ} \mathrm{C}$ for $3 \mathrm{~h}$. The catalyst was characterized using $X$-ray diffraction, Fourier transform infrared spectroscopy, Thermogravimetric analysis, Scanning electron microscopy, Hammett titration method, and ion exchange method. The catalyst had a basicity of $12.57 \mathrm{mmol} / \mathrm{g}$ and a basic strength of $9.8<H<17.2$. It showed good catalytic activity in biodiesel synthesis. The maximum biodiesel yield obtained was $89 \%$ for the following reaction conditions: catalyst loading of $4 \mathrm{wt} \%$, a reaction temperature of $65^{\circ} \mathrm{C}$, the methanol-to-oil molar ratio of 12:1, and reaction time of $3 \mathrm{~h}$. Thus, it was found that harmful waste can be used as an effective solid base heterogeneous catalyst.
\end{abstract}

\section{Keywords}

biodiesel, transesterification, water sludge, soybean oil

\footnotetext{
${ }^{1}$ Department of Chemical Engineering,

Malaviya National Institute of Technology Jaipur-302017, India

${ }^{2}$ Department of Chemical and Biological Engineering,

University of Saskatchewan, Canada S7N 5A9, Canada

*Corresponding author, e-mail: magarwal.chem@mnit.ac.in
}

\section{Introduction}

Due to environmental issues and the high cost of crude oil resources, researchers are exploring alternative energy sources such as biofuels [1-2]. Biodiesel can be obtained from the transesterification of vegetable oils (e.g., thumba oil, soybean oil, and linseed oil) [3-4]. During transesterification, vegetable oil reacts with alcohol in the presence of a homogeneous or heterogeneous catalyst to produce biodiesel. Soybean oil is found to be the main feedstock for biodiesel synthesis among all vegetable oils because it has low free fatty acid (FFA) content. This overcomes a two-step transesterification process with a high biodiesel yield or conversion [5]. Various homogeneous catalysts have been studied for biodiesel synthesis, including $\mathrm{NaOH}, \mathrm{KOH}$, and $\mathrm{MeOH}$, which give a good biodiesel yield with better biodiesel properties. In spite of these advantages, homogeneous catalysts have some drawbacks (i.e. their separation is complex, they require to be purified, and they cannot be reused after the reaction) [6-7]. Therefore, to overcome these shortcomings, the focus now is on exploring solid heterogeneous catalysts, which have many advantages: they are cheap, noncorrosive, and recyclable; have a fast reaction rate, and do not require any water purification step [8]. Unfortunately, highly active heterogeneous catalysts are complicated to use, expensive, and need special skills to operate [9]. Accordingly, it is a big challenge to investigate an ideal solid basic catalyst that is highly efficient, is cost effective, and environment friendly for biodiesel production. Among the various heterogeneous catalysts, $\mathrm{CaO}$ derived from waste material is found to be the best heterogeneous base catalyst for biodiesel production. Researchers have investigated catalysts from wastes such as marble slurry, red mud, shells, fly ash, and bones [9-12]. These waste materials as the main source of $\mathrm{CaO}$ were found to be the best heterogeneous base catalysts for biodiesel synthesis. Thus, the development of catalysts from waste with good catalytic activity is highly desirable for low cost biodiesel production. Water treatment precipitate also known as water sludge is generated as a solid waste after defluoridation of drinking water using the Nalgonda technique. The well-known Nalgonda technique for defluoridation 
involves coagulation. Here, alum is added with $\mathrm{CaCO}_{3}$ as a $\mathrm{pH}$ controller to the form of alumino-fluoro complexes. Waste sludge disposal causes serious problems (i.e., a health hazard and environmental issues). Water sludge mainly consists of $\mathrm{CaCO}_{3}$ and alumina fluoro complexes which indicate that this can be used as a promising feedstock to prepare effective catalysts for biodiesel production. Therefore, in this study, a solid base catalyst was synthesized from drinking water defluoridation sludge after modification and was explored for biodiesel synthesis.

The aim of this study was to prepare a highly basic heterogeneous catalyst derived from drinking water treatment sludge for biodiesel production from soybean oil. The catalyst was characterized using X-ray diffraction (XRD), Fourier transform infrared (FTIR), Thermogravimetric analysis (TGA), scanning electron microscopy (SEM) with energy-dispersive X-ray spectroscopy (EDS), Hammett titration method, and ion exchange method. Gas chromatography (GC) analysis of the synthesized biodiesel was also performed to analyse the quality of the biodiesel produced.

\section{Materials and Methods}

\subsection{Materials and chemicals}

Water sludge was obtained from drinking water defluoridation by using the Nalgonda technique performed at MNIT, Jaipur, India. Soybean oil was procured from a local vendor in Jaipur. Methanol and heptane of analytical grade (99\% purity) were purchased from Merck Limited, Mumbai, India. Methyl heptadecanoate ( $>99.0 \%$ purity) used as an internal standard for GC was purchased from Sigma-Aldrich, New Delhi, India.

\subsection{Quality analysis of soybean oil}

The physicochemical properties of soybean oil were measured and are as given in Table 1.

Table 1 Characteristics of soybean oil

\begin{tabular}{ll}
\hline Properties of soybean oil & Results \\
\hline Density $(\mathrm{g} / \mathrm{ml})$ & 0.85 \\
Kinematic viscosity at $40{ }^{\circ} \mathrm{C}(\mathrm{cSt})$ & 15.55 \\
Acid value $(\mathrm{mg}$ of $\mathrm{KOH} / \mathrm{g}$ of oil) & 1.21 \\
FFA & 0.6 \\
Cloud point $\left({ }^{\circ} \mathrm{C}\right)$ & -2 \\
Pour point $\left({ }^{\circ} \mathrm{C}\right)$ & -3 \\
Flash point $\left({ }^{\circ} \mathrm{C}\right)$ & 260 \\
Fire point $\left({ }^{\circ} \mathrm{C}\right)$ & 275 \\
$\begin{array}{l}\text { Saponification value } \\
\text { (mg of KOH} / \mathrm{g} \text { of oil })\end{array}$ & 195 \\
Molecule weight $(\mathrm{g} / \mathrm{mol})$ & 866.30 \\
Ester value & 195.20 \\
\hline
\end{tabular}

\subsection{Catalyst preparation}

The water precipitate obtained after coagulation and flocculation of defluoridation in which alum was added with lime led to the generation of water sludge. This water sludge was rinsed with distilled water several times to remove impurities and undesired material and then dried in a hot air oven at $105{ }^{\circ} \mathrm{C}$ for about $24 \mathrm{~h}$. The dried water sludge was subsequently crushed into a fine powder named as uncalcined WS and calcined in a muffle furnace at $950{ }^{\circ} \mathrm{C}$ for $3 \mathrm{~h}$ to synthesize the catalyst, which was named Calcined water sludge (CWS).

\subsection{Catalyst characterization}

Catalysts were subjected to thermogravimetric analysis (TGA) from $27{ }^{\circ} \mathrm{C}$ to $900{ }^{\circ} \mathrm{C}$ using a thermal analyser under the $\mathrm{N}_{2}$ atmosphere at a heating rate of $20{ }^{\circ} \mathrm{C}$ per min. XRD analysis was carried out using an X-Pert Pro powder analytical instrument equipped with a $\mathrm{Cu}$ anode under the following conditions: $40 \mathrm{kV}$ tube voltage, $40 \mathrm{~mA}$ tube current, and the samples were scanned at $2 \theta=10-90^{\circ}$. The FTIR (Fourier Transform Infrared Spectroscopy) spectrum of the sample was obtained by using an FTIR spectrometer (Model-Perkin Elmer spectra two) in the range of $400-4500 \mathrm{~cm}^{-1}$ and a $\mathrm{KBr}$ pellet.

The resolution was set to $0.5 \mathrm{~cm}^{-1}$, and total number of runs were 16 in FTIR spectroscopy. Scanning electron microscopy (SEM) with EDS was carried out using an FESEM FEI system (Model-Nova Nano 450). Catalytic basicity was also examined by the Hammett method and ion exchange method.

\subsection{Biodiesel production by transesterification process}

In this process, $100 \mathrm{ml}$ of soybean oil was preheated and mixed with the catalyst (Calcined WS) and methanol in the flask with continuous stirring. Transesterification reaction was performed at $65^{\circ} \mathrm{C}$ with a $12: 1$ methanol- to-oil molar ratio, and $4 \mathrm{wt} \%$ catalyst loading in $3 \mathrm{~h}$. The reaction mixture was transferred to a separating funnel for separation of phases (i.e., biodiesel, glycerol, and catalyst). The excess amount of methanol was recovered from biodiesel in a rotary evaporator. The FAME thus obtained was stored for further characterization.

\subsection{Biodiesel Characterization}

The biodiesel obtained was characterized by GC analysis using the European regulated procedure EN-14103 by dissolving the ester layer $(250 \mathrm{mg})$ in $\mathrm{n}$-hexane $(5 \mathrm{ml})$ containing the solution of an internal standard, namely, methyl heptadecanoate (10 g/L of $\mathrm{C} 17$ ester in hexane). The biodiesel yield was measured as follows:

$$
\text { Yield } \%=\frac{\sum \boldsymbol{A}-\boldsymbol{A M H}}{\boldsymbol{A M H}} \times \frac{\boldsymbol{C M H} \times \boldsymbol{V M H}}{\boldsymbol{m}} \times 100 \%
$$

where A is the total peak area from methyl ester, AMH is the area of methyl heptadecanoate, for which the response factor 
is equal to that of ester; $\mathrm{CMH}$ is the concentration in $\mathrm{mg} / \mathrm{ml}$ of the methyl heptadecanoate $(10 \mathrm{mg} / \mathrm{ml})$; $\mathrm{VMH}$ is the volume in $\mathrm{ml}$ of the methyl heptadecanoate solution $(5 \mathrm{ml}) ; \mathrm{m}$ is the mass in $\mathrm{mg}$ of the sample (250 $\mathrm{mg})$ [13].

A gas chromatograph (Model: Master GC Dani Instruments, Italy) with a $30 \mathrm{~m}$ capillary column length, Inner Diameter $0.32 \mathrm{~mm}$, and film thickness $0.25 \mu \mathrm{m}$ was used for biodiesel analysis. The chromatographic conditions were as follows: detector: $280{ }^{\circ} \mathrm{C}$, injector: $240{ }^{\circ} \mathrm{C}$, column temperature: 100 $200{ }^{\circ} \mathrm{C}$ at a flow rate of $40{ }^{\circ} \mathrm{C} \mathrm{min}-1,200-232{ }^{\circ} \mathrm{C}$ at $2{ }^{\circ} \mathrm{C} \mathrm{min}{ }^{-1}$, and $232-280{ }^{\circ} \mathrm{C}$ at $30{ }^{\circ} \mathrm{C} \mathrm{min}{ }^{-1}$. High purity nitrogen (purity $\geq 99.9 \%$ ) was used as the carrier gas.

\section{Results and discussion}

\subsection{Catalyst characterization}

Thermal stability of uncalcined WS was investigated by TGA. The obtained thermograph is depicted in Fig. 1. Carbon dioxide evolved from the precursor with a further weight loss of $46 \%$ between 600 and $800{ }^{\circ} \mathrm{C}$. Above $900{ }^{\circ} \mathrm{C}$, the weight loss remained constant. These results suggest that that carbonate was completely converted to metal oxide by calcining at $950{ }^{\circ} \mathrm{C}$. Therefore, calcination was done at $950^{\circ} \mathrm{C}[14,6-7]$.

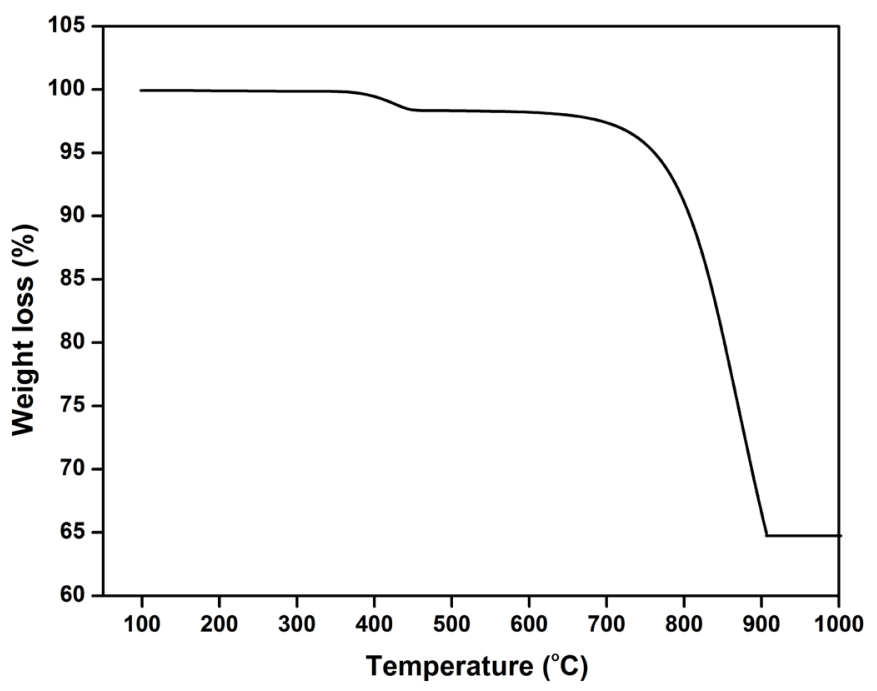

Fig. 1 TGA analysis of the WS catalyst

Fig. 2 shows the XRD pattern of uncalcined WS and calcined WS. The uncalcined WS mainly consists of lime and Aluminofluoro complexes with some traces of sodium fluoride as shown by different peaks at $2 \theta$ around $27.22^{\circ}, 31.06^{\circ}, 33.10^{\circ}, 36.09^{\circ}$, $37.82^{\circ}$, and $45.82^{\circ}$ (Fig. 1). After the calcination, intense sharp peaks of $\mathrm{CaO}$ and $\Upsilon$-alumina were observed at $2 \theta$ around $32.12^{\circ}$, $37.28^{\circ}$, and $53.76^{\circ}$ [14]. Our catalyst was composed of $\mathrm{CaO}$ and $\Upsilon$-alumina, which were the main active components present in large amounts compared to other reactants. Thus, their diffraction peaks were too strong in intensity to cover the diffraction peaks of other crystalline phases. Marban et al. and Granados et al. also reported that the diffraction peaks of one oxide would cover those of others when its content was too high [15-16].
Similarly, it is conceivable that the diffraction peaks of other crystalline phases were covered by the diffraction peaks of $\mathrm{CaO}$.

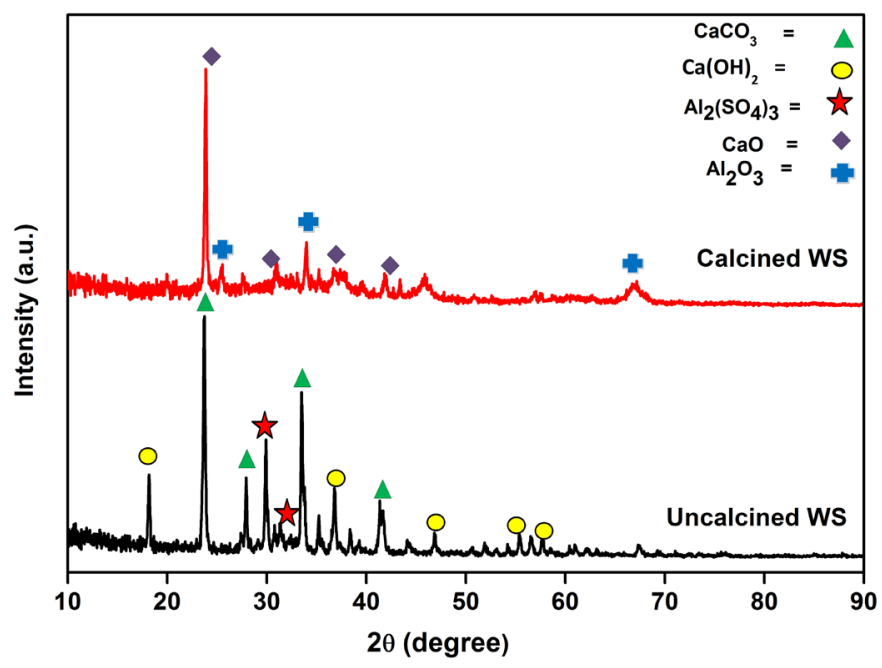

Fig. 2 XRD pattern of the catalysts.

Fig. 3 shows the FTIR spectra of uncalcined WS and calcined WS. The spectra of uncalcined WS showed a major broad adsorption band at 1462 and $845 \mathrm{~cm}^{-1}$, which confirms the presence of a $\mathrm{CO}_{3}{ }^{2-}$ group. The FTIR spectra of uncalcined WS also reveal the presence of a hydroxide stretching band vibration at $3463 \mathrm{~cm}^{-1}$. The other band for the same sample confirms the presence of an $\mathrm{SO}_{4}{ }^{2-}$ group at $1196 \mathrm{~cm}^{-1}$ and 680 $\mathrm{cm}^{-1}$ [17]. After calcination at $950{ }^{\circ} \mathrm{C}$, a sharp band starts to appear at $3642 \mathrm{~cm}^{-1}$, which represents the $\mathrm{OH}$ stretching band. These bands at a higher temperature indicate that the bands are shifted to a high-energy level due to a decrease in the reduced mass of the functional group attached to carbonate ion [18]. A wide pattern extending from 400 to $850 \mathrm{~cm}^{-1}$ also confirms the formation of $\Upsilon$-alumina after calcination of WS. These results are in agreement with those obtained from the XRD measurement of catalyst samples [14].

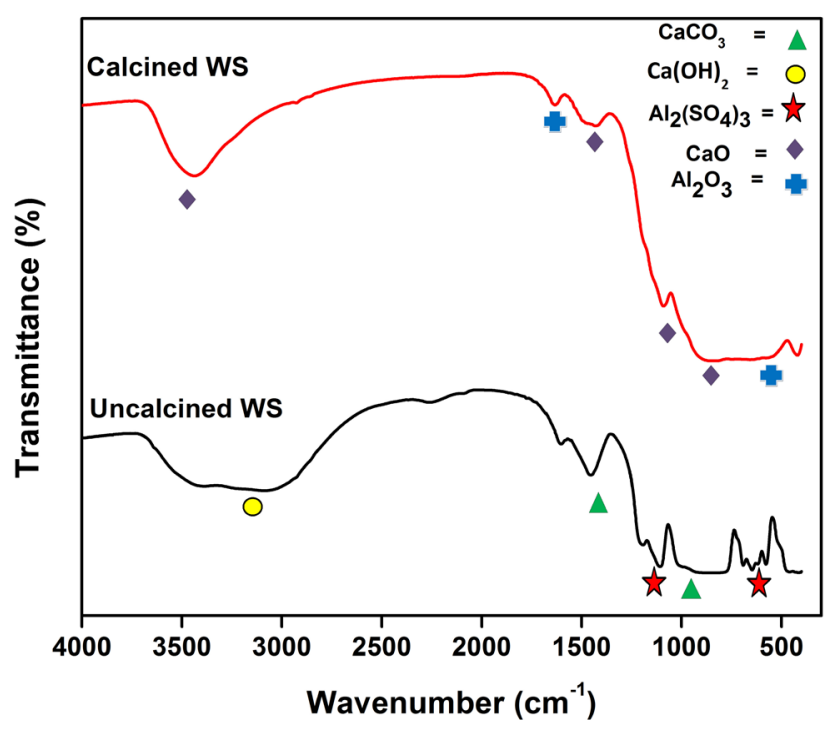

Fig. 3 FTIR spectra of the catalysts. 
The Hammett method was used for basicity determination as described in the literature [19]. Typically, $300 \mathrm{mg}$ of the catalyst sample was dissolved in $1 \mathrm{ml}$ of Hammett indicators and $10 \mathrm{ml}$ of methanol. Equilibrium was attained in 1-2 hours during which no colour change was observed. Basic strength is defined as being stronger than the weakest indicator, which exhibits a colour change, and weaker than the strongest indicator that produces no colour change. Hammett indicators include bromthymol $\left(\mathrm{H}_{-}=7.2\right)$, phenolphthalein $\left(\mathrm{H}_{-}=9.8\right)$, indigo carmine $\left(\mathrm{H}_{-}=12.2\right), 2$,4-dinitroaniline $\left(\mathrm{H}_{-}=15.0\right)$, 4chloride2-nitroaniline $\left(\mathrm{H}_{-}=17.2\right)$, and nitroaniline $\left(\mathrm{H}_{-}=18.4\right)$.

Table 2 indicates that CWS has a higher basicity than uncalcined WS which is directly proportional to the largest surface area of the catalyst as reported in the literature [20]. The results obtained reveal that calcined WS has $12.57 \mathrm{mmol} / \mathrm{g}$ of total basicity which is good enough for it to be an effective basic catalyst in biodiesel synthesis.

Table 2 Basicity of the solid catalyst.

\begin{tabular}{lll}
\hline Name of sample & $\begin{array}{l}\text { Basic strength of the } \\
\text { samples, }\left(\mathrm{H}_{-}\right)\end{array}$ & $\begin{array}{l}\text { Total basicity of the } \\
\text { samples, }(\mathrm{mmol} / \mathrm{g})\end{array}$ \\
\hline Uncalcined WP & $7.2<\mathrm{H}_{-}<12.0$ & 4.26 \\
Calcined WP & $9.8<\mathrm{H}_{-}<17.2$ & 12.57 \\
\hline
\end{tabular}

The Ion Exchange method was applied for investigating the basic sites of a developed catalyst by a process explained in the literature [20]. Typically, a $\mathrm{pH}$ electrode (0-14 $\mathrm{pH}$ range) was dipped in $20 \mathrm{ml}$ of $0.005 \mathrm{M}$ benzoic acid standardized solution, until a constant $\mathrm{pH}$ value was observed (i.e., $\mathrm{pH}=3$ ). About $1 \mathrm{~g}$ of the catalyst was added, and the $\mathrm{pH}$ was measured in terms of time for $1 \mathrm{~h}$. The $\mathrm{pH}$ analysis in terms of time for the prepared catalyst is shown in Fig. 4. It was found that the basicity neutralization rate is very high for calcined WS than for other catalysts and constant $\mathrm{pH}$ was observed after $25 \mathrm{~min}$. The highest basicity of the calcined WS showed the highest catalytic activity which is directly proportional to the largest surface area and highest basic sites of the catalyst.

Fig. 5 shows the SEM images of Uncalcined and calcined WS. Uncalcined WS shows an irregular, rough, and layered crystal structure with a smaller surface area as shown in Fig. 2(a). After calcination at $950{ }^{\circ} \mathrm{C}$ for $3 \mathrm{~h}$, as shown in Fig. 2(b), the crystal structure changed and pores were observed. This provides a larger specific surface area of the catalyst which is an important characteristic of heterogeneous catalysts [21-24].

To investigate the effect of calcination temperature on the catalyst surface, EDS was also carried out. The EDS analysis revealed that the chemical composition of the catalyst surface was highly influenced at higher calcination temperatures.

Table 3 gives the elemental composition of the uncalcined WS calcined and CWS at high temperatures. The results indicated that the uncalcined WS and calcined snail WS mainly contain aluminum, and calcium with some other element of F, and Na. Sulphur is not detected after calcination at high temperature.

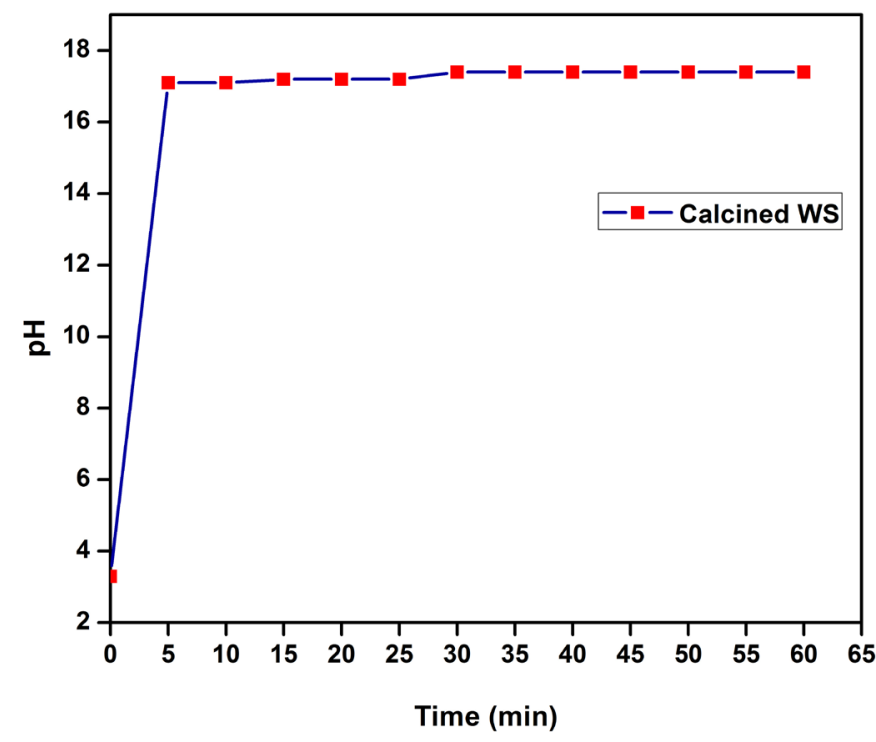

Fig. 4 Basicity determination in terms of $\mathrm{pH}$.

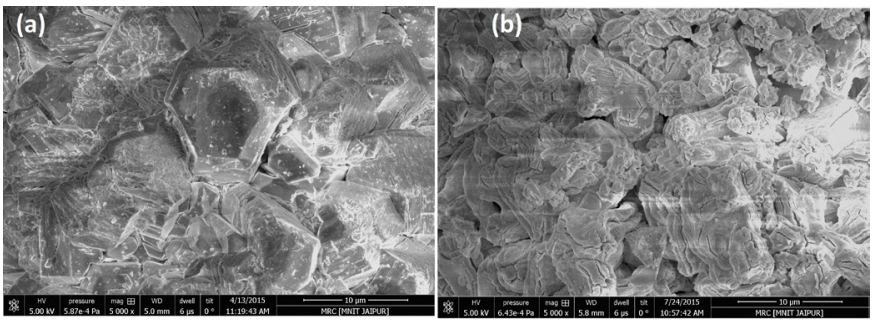

Fig. 5 SEM Images of (a) Uncalcined WS and (b) calcined WS.

Table 3 EDS analysis of the catalysts.

\begin{tabular}{lllll}
\hline \multirow{2}{*}{ Element } & \multicolumn{2}{c}{ Uncalcined WS } & \multicolumn{2}{c}{ CWS } \\
\cline { 2 - 5 } & Weight $\%$ & Atomic \% & Weight \% & Atomic \% \\
\hline $\mathrm{O}$ & 52.44 & 65.56 & 53.21 & 67.28 \\
$\mathrm{Al}$ & 25.85 & 18.06 & 28.15 & 18.70 \\
$\mathrm{Ca}$ & 15.76 & 11.88 & 17.32 & 11.92 \\
$\mathrm{~S}$ & 3.95 & 2.46 & 0.00 & 0.00 \\
$\mathrm{~F}$ & 1.65 & 1.74 & 1.09 & 1.80 \\
$\mathrm{Na}$ & 0.35 & 0.30 & 0.23 & 0.30 \\
\hline
\end{tabular}

Table 4 shows the comparative study of the heterogeneous catalyst from waste resources for biodiesel synthesis in terms of transesterification reaction conditions, catalyst basicity, and biodiesel yield. It can be justified that a small amount of the developed highly basic catalyst (4 wt\%) and the methanol-to-oil molar ratio (12:1) in $3 \mathrm{~h}$ led to the highest biodiesel yield and better properties of biodiesel than other reported waste catalysts. 
Table 4 Comparison of the solid heterogeneous catalyst derived from waste sources for biodiesel synthesis.

\begin{tabular}{|c|c|c|c|c|c|c|c|c|c|}
\hline $\begin{array}{l}\text { Catalyst } \\
\text { from waste } \\
\text { resources }\end{array}$ & Oil & $\begin{array}{l}\text { Calcination } \\
\text { conditions }\end{array}$ & $\begin{array}{l}\text { Temperature } \\
\left({ }^{\circ} \mathrm{C}\right)\end{array}$ & $\begin{array}{l}\text { Alcohol } \\
\text { to oil } \\
\text { molar ratio }\end{array}$ & $\begin{array}{l}\text { Time } \\
\text { (h) }\end{array}$ & $\begin{array}{l}\text { Catalyst } \\
\text { loading } \\
(\mathrm{wt} \%)\end{array}$ & Basic strength & $\begin{array}{l}\text { Yield (Y) or } \\
\text { Conversion } \\
\text { (C) }(\%)\end{array}$ & Reference \\
\hline Egg shell & Jatropha oil & $\begin{array}{l}900{ }^{\circ} \mathrm{C} \\
4 \mathrm{~h}\end{array}$ & 50 & $5: 1$ & 0.5 & 5 & $7.2<\mathrm{H}<9.8$ & $C=45.6$ & 7 \\
\hline Abalone shell & Palm oil & $\begin{array}{l}900^{\circ} \mathrm{C} \\
4 \mathrm{~h}\end{array}$ & 65 & $12: 1$ & 3 & 7 & $15<\mathrm{H}<18.4$ & $\mathrm{Y}=87.5$ & 25 \\
\hline Egg shell & Waste frying oil & $\begin{array}{l}900{ }^{\circ} \mathrm{C} \\
2.5 \mathrm{~h}\end{array}$ & 65 & $12: 1$ & 1 & 5 & $12.2<\mathrm{H}<15$ & $Y=94.5$ & 26 \\
\hline $\begin{array}{l}\text { White } \\
\text { marlstone }\end{array}$ & Coconut oil & $\begin{array}{l}1000^{\circ} \mathrm{C} \\
1.5 \mathrm{~h}\end{array}$ & 60 & $6: 1$ & 2 & 15 & $10.1<\mathrm{H}_{-}<15.0$ & $\mathrm{Y}=97$ & 27 \\
\hline $\begin{array}{l}\text { White } \\
\text { marlstone }\end{array}$ & Coconut oil & $\begin{array}{l}900^{\circ} \mathrm{C} \\
3 \mathrm{~h}\end{array}$ & 60 & $6: 1$ & 2 & 15 & $10.1<\mathrm{H}_{-}<15.0$ & $Y=94$ & 27 \\
\hline Oyster shell & Soybean oil & $\begin{array}{l}1000^{\circ} \mathrm{C} \\
3 \mathrm{~h}\end{array}$ & $65-70$ & - & 5 & 25 & - & $Y=74$ & 28 \\
\hline Mussel shell & Soybean oil & $\begin{array}{l}1050^{\circ} \mathrm{C} \\
2 \mathrm{~h}\end{array}$ & 60 & $24: 1$ & 8 & 12 & - & $Y=94$ & 29 \\
\hline Snail shell & Soybean oil & $\begin{array}{l}800{ }^{\circ} \mathrm{C} \\
3 \mathrm{~h}\end{array}$ & 65 & $9: 1$ & 3.5 & 6 & $9.8<\mathrm{H}_{-}<17.2$ & $\mathrm{Y}=90$ & 21 \\
\hline Water sludge & Soybean oil & $\begin{array}{l}950{ }^{\circ} \mathrm{C} \\
3 \mathrm{~h}\end{array}$ & 65 & $12: 1$ & 3 & 4 & $9.8<\mathrm{H}<17.2$ & $\mathrm{Y}=89$ & $\begin{array}{l}\text { present } \\
\text { study }\end{array}$ \\
\hline
\end{tabular}

\subsection{Biodiesel characterization}

The characteristics of soybean biodiesel were measured and compared with ASTM D6751 Standard and found to be within the prescribed limit (Table 5). This shows that the developed catalyst derived from water sludge has immense potential to produce biodiesel on a large scale from soybean oil.

\subsubsection{GC analysis}

Biodiesel yield was determined using GC analysis (Fig. 6). The figure shows a typical Chromatogram. The chromatogram of soybean biodiesel shows the presence of Fatty acid methyl esters such as palmitic acid (19.5 min), stearic acid (24.6 min), oleic acid (25.2 min), linoleic acid (26.5 min), and linolenic acid (28.0 $\mathrm{min})$.
Table 5 Quality analysis of soybean biodiesel

\begin{tabular}{llll}
\hline Biodiesel Properties & Unit & $\begin{array}{l}\text { Soybean biodiesel } \\
\text { from calcined WS }\end{array}$ & $\begin{array}{l}\text { ASTM } \\
\text { Standard }\end{array}$ \\
\hline Density & $\mathrm{g} / \mathrm{ml}$ & 0.89 & $0.86-0.90$ \\
$\begin{array}{l}\text { Kinematic viscosity } \\
\left(\text { at } 40{ }^{\circ} \mathrm{C}\right)\end{array}$ & $\mathrm{cSt}$ & 3.9 & $1.9-6.0$ \\
Acid value & $\mathrm{mg}$ of $\mathrm{KOH} / \mathrm{g}$ & 0.5 & 0.50 \\
of oil & ${ }^{\circ} \mathrm{C}$ & 9 & -3 to 12 \\
Ploud point & ${ }^{\circ} \mathrm{C}$ & -3 & -15 to 10 \\
Flash point & ${ }^{\circ} \mathrm{C}$ & 159 & $130-170$ \\
\hline
\end{tabular}

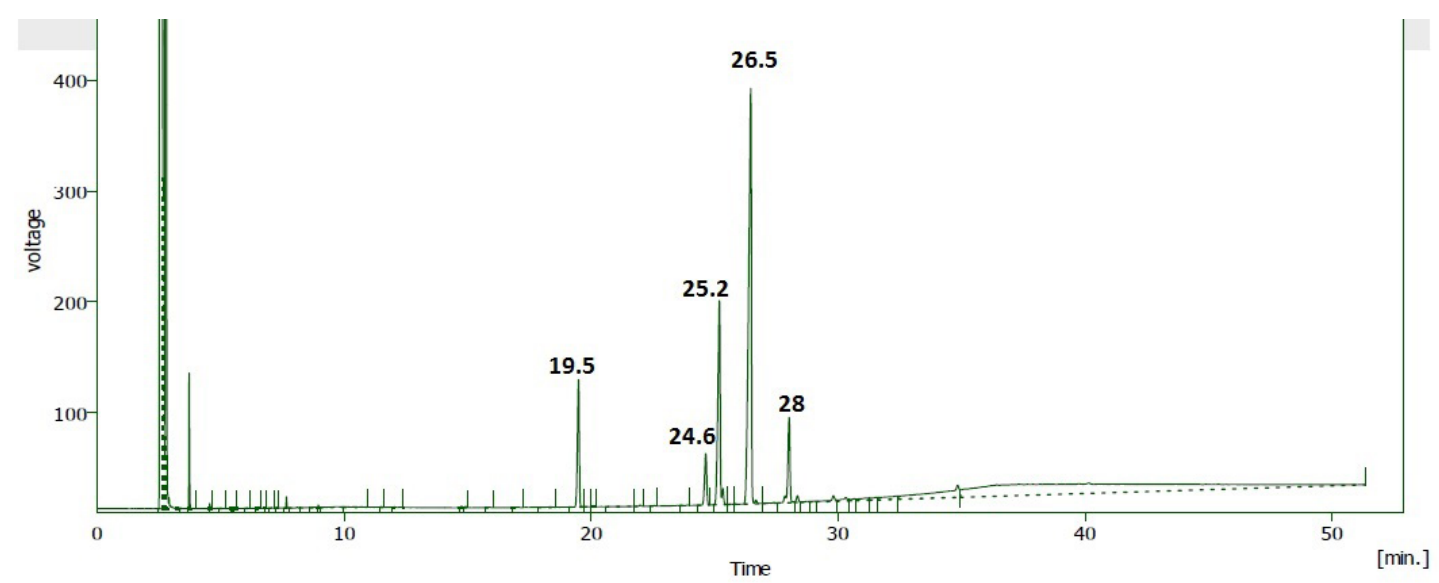

Fig. 6 GC analysis of soybean biodiesel 


\section{Conclusion}

Soybean oil can be efficiently converted into biodiesel using water defluoridation sludge-derived modified heterogeneous catalyst. Catalyst characterization results reveal that the catalyst exhibits stronger basicity $(12.54 \mathrm{mmol} / \mathrm{g})$, which is directly proportional to high catalytic activity. This results in a good biodiesel yield $(89 \%)$ through transesterification at $65{ }^{\circ} \mathrm{C}$, methanol-to-oil molar ratio of 12:1, and catalyst loading of 4 $w t \%$. Biodiesel yield can also be increased after the modification of the catalyst by adding some highly basic functional groups on it. Additionally, this catalyst is also very promising for biodiesel production from the economic and environmental points of view because it allows the use of hazardous waste. This thereby reduces costs, saves resources, and protects the environment and public health.

\section{Acknowledgement}

This work was supported by MNIT Jaipur, India as part of the Ph.D. research and funded by the same.

\section{References}

[1] Viriya-Empikul, N., Krasae, P., Puttasawat, B., Yoosuk, B., Chollacoop, N., Faungnawakij, K. "Waste shells of mollusk and egg as biodiesel productioncatalysts." Bioresourcetechnology. 101(10), pp. 3765-3767. 2010. https://doi.org/10.1016/j.biortech.2009.12.079

[2] Xu, W., Gao, L., Wang, S., Xiao, G. "Biodiesel production in a membrane reactor using MCM-41 supportedsolidacidcatalyst." Bioresourcetechnology. 159, pp.286-291.2014. https://doi.org/10.1016/j.biortech.2014.03.004

[3] Chen, G., Shan, R., Shi, J., Liu, C., Yan, B. "Biodiesel production from palm oil using active and stable K doped hydroxyapatite catalysts." Energy Conversion and Management. 98, pp. 463-469. 2015. https://doi.org/10.1016/j.enconman.2015.04.012

[4] Niju, S., Begum, K. M. S., Anantharaman, N. "Enhancement of biodiesel synthesis over highly active $\mathrm{CaO}$ derived from natural white bivalve clam shell." Arabian Journal of Chemistry. 9(5), pp. 633-639. 2016. https://doi.org/10.1016/j.arabjc.2014.06.006

[5] Palacios-Nereo, F. J., Olivares-Carrillo, P., de los Ríos, A. P., Quesada-Medina, J. "High-yield non-catalytic supercritical transesterification of soybean oil to biodiesel induced by gradual heating in a batch reactor." The Journal of Supercritical Fluids. 111, pp. 135-142. 2016. https://doi.org/10.1016/j.supflu.2016.01.022

[6] Sirisomboonchai, S., Abuduwayiti, M., Guan, G., Samart, C., Abliz, S., Hao, X., Abudula, A. "Biodiesel production from waste cooking oil using calcined scallop shell as catalyst." Energy Conversion and Management. 95, pp. 242-247. 2015.

https://doi.org/10.1016/j.enconman.2015.02.044

[7] Joshi, G., Rawat, D. S., Lamba, B. Y., Bisht, K. K., Kumar, P., Kumar, N., Kumar, S. "Transesterification of Jatropha and Karanja oils by using waste egg shell derived calcium based mixed metal oxides." Energy Conversion and Management. 96, pp. 58-267. 2015.

https://doi.org/10.1016/j.enconman.2015.02.061

[8] Torres-Rodríguez, D. A., Romero-Ibarra, I. C., Ibarra, I. A., Pfeiffer, H. "Biodiesel production from soybean and Jatropha oils using cesium impregnated sodium zirconate as a heterogeneous base catalyst." Renewable Energy. 93, pp. 323-331.2016.

https://doi.org/10.1016/j.renene.2016.02.061
[9] Liu, Q., Xin, R., Li, C., Xu, C., Yang, J. "Application of red mud as a basic catalyst for biodiesel production." Journal of Environmental Sciences. 25(4), pp. 823-829. 2013.

https://doi.org/10.1016/S1001-0742(12)60067-9

[10] Suryaputra, W., Winata, I., Indraswati, N., Ismadji, S. "Waste capiz (Amusium cristatum) shell as a new heterogeneous catalyst for biodiesel production." Renewable Energy. 50, pp. 795-799. 2013. https://doi.org/10.1016/j.renene.2012.08.060

[11] Boey, P. L., Maniam, G. P., Hamid, S. A., Ali, D. M. H "Utilization of waste cockle shell (Anadara granosa) in biodiesel production from palm olein: optimization using response surface methodology." Fuel. 90(7), pp. 2353-2358. 2011. https://doi.org/10.1016/j.fuel.2011.03.002

[12] Chakraborty, R., Bepari, S., Banerjee, A. "Transesterification of soybean oil catalyzed by fly ash and egg shell derived solid catalysts." Chemical Engineering Journal. 165(3), pp. 798-805. 2010.

https://doi.org/10.1016/j.cej.2010.10.019

[13] Suryaputra, W., Winata, I., Indraswati, N., Ismadji, S. "Waste capiz (Amusium cristatum) shell as a new heterogeneous catalyst for biodiesel production." Renewable Energy. 50, pp. 795-799. 2013. https://doi.org/10.1016/j.renene.2012.08.060

[14] Zhang, P., Han, Q., Fan, M., Jiang, P. "A novel waste water scale-derived solid base catalyst for biodiesel production." Fuel. 124, pp. 66-72. 2014. https://doi.org/10.1016/j.fuel.2014.01.091

[15] Marbán, G., Fuertes, A. B. "Highly active and selective $\mathrm{CuO}$ x/CeO catalyst prepared by a single-step citrate method for preferential oxidation of carbon monoxide." Applied Catalysis B: Environmental. 57(1), pp. 43-53. 2005.

https://doi.org/10.1016/j.apcatb.2004.10.011

[16] Granados, M. L., Gurbani, A., Mariscal, R., Fierro, J. L. G. "Deterioration of the oxygen storage and release properties of CeZrO 4 by incorporation of calcium." Journal of Catalysis. 256(2), pp. 172 182. 2008. https://doi.org/10.1016/j.jcat.2008.03.011

[17] Jafar-Tafreshi, M., Bustanafruz, F., Fazli, M. "Studies on Thermal Decomposition of Aluminium Sulfate to Produce Alumina Nano Structure." Journal of Nanostructures. 2(4), pp. 463-468. 2012. https://doi.org/10.7508/jns.2012.04.008

[18] Lee, S. L., Wong, Y. C., Tan, Y. P., Yew, S. Y. "Transesterification of palm oil to biodiesel by using waste obtuse horn shell-derived $\mathrm{CaO}$ catalyst." Energy Conversion and Management. 93, pp. 282-288. 2015. https://doi.org/10.1016/j.enconman.2014.12.067

[19] Tanabe, K., Yamaguchi, T. "Basicity and acidity of solid surfaces." In: 13th Discussion Meeting on Catalysis, Sapporo. 1963.

[20] Corro, G., Sánchez, N., Pal, U., Bañuelos, F. "Biodiesel production from waste frying oil using waste animal bone and solar heat." Waste Management. 47, pp.105-113. 2016. https://doi.org/10.1016/j.wasman.2015.02.001

[21] Gupta, J., Agarwal, M. "Preparation and characterization of highly active solid base catalyst from snail shell for biodiesel production." Biofuels, pp. 1-10. 2016. https://doi.org/10.1080/17597269.2016.1200862

[22] Nisar, J., Razaq, R., Farooq, M., Iqbal, M., Khan, R. A., Sayed, M., Shah, A., ur Rahman, I. "Enhanced biodiesel production from Jatropha oil using calcined waste animal bones as catalyst." Renewable Energy. 101, pp. 111-119. 2017. https://doi.org/10.1016/j.renene.2016.08.048

[23] Yin, X., Duan, X., You, Q., Dai, C., Tan, Z., Zhu, X. "Biodiesel production from soybean oil deodorizer distillate using calcined duck eggshell as catalyst." Energy Conversion and Management. 112, pp.199-207. 2016. https://doi.org/10.1016/j.enconman.2016.01.026 
[24] Jaiyen, S., Naree, T., Ngamcharussrivichai, C. "Comparative study of natural dolomitic rock and waste mixed seashells as heterogeneous catalysts for the methanolysis of palm oil to biodiesel." Renewable Energy. 74, pp. 433-440. 2015. https://doi.org/10.1016/j.renene.2014.08.050

[25] Chen, G. Y., Shan, R., Yan, B. B., Shi, J. F., Li, S. Y., Liu, C. Y. "Remarkably enhancing the biodiesel yield from palm oil upon abalone shell-derived $\mathrm{CaO}$ catalysts treated by ethanol." Fuel Processing Technology. 143, pp. 110-117. 2016

https://doi.org/10.1016/j.fuproc.2015.11.017

[26] Niju, S., Meera, K. M., Begum, S., Anantharaman, N. "Modification of egg shell and its application in biodiesel production." Journal of Saudi Chemical Society. 18(5), pp. 702-706. 2014.

https://doi.org/10.1016/j.jscs.2014.02.010
[27] Jaggernauth-Ali, P., John, E., Bridgemohan, P. "The application of calcined marlstones as a catalyst in biodiesel production from high free fatty acid coconut oil." Fuel. 158, pp. 372-378. 2015. https://doi.org/10.1016/j.fuel.2015.05.022

[28] Nakatani, N., Takamori, H., Takeda, K., Sakugawa, H. "Transesterification of soybean oil using combusted oyster shell waste as a catalyst." Bioresource Technology. 100(3), pp. 1510-1513. 2009. https://doi.org/10.1016/j.biortech.2008.09.007

[29] Rezaei, R., Mohadesi, M., Moradi, G. R. "Optimization of biodiesel production using waste mussel shell catalyst." Fuel. 109, pp. 534-541. 2013. https://doi.org/10.1016/j.fuel.2013.03.004 